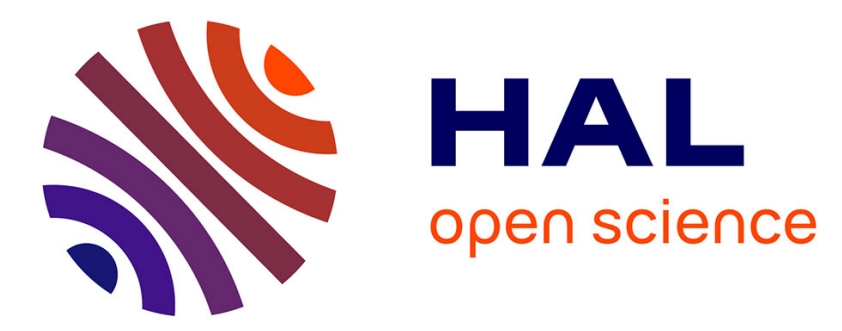

\title{
Methylmercury complexes: Selection of thermodynamic properties and application to the modelling of a column experiment
}

\author{
Philippe Blanc, André Burnol, Nicolas C.M. Marty, Jennifer Hellal, Valérie
} Guérin, Valérie Laperche

\section{To cite this version:}

Philippe Blanc, André Burnol, Nicolas C.M. Marty, Jennifer Hellal, Valérie Guérin, et al.. Methylmercury complexes: Selection of thermodynamic properties and application to the modelling of a column experiment. Science of the Total Environment, 2018, 621, pp.368-375. 10.1016/j.scitotenv.2017.11.259 . hal-02860414

\section{HAL Id: hal-02860414 https://hal-brgm.archives-ouvertes.fr/hal-02860414}

Submitted on 19 Aug 2020

HAL is a multi-disciplinary open access archive for the deposit and dissemination of scientific research documents, whether they are published or not. The documents may come from teaching and research institutions in France or abroad, or from public or private research centers.
L'archive ouverte pluridisciplinaire HAL, est destinée au dépôt et à la diffusion de documents scientifiques de niveau recherche, publiés ou non, émanant des établissements d'enseignement et de recherche français ou étrangers, des laboratoires publics ou privés.

\section{(c)(1)}

Distributed under a Creative Commons Attribution| 4.0 International License 


\title{
METHYLMERCURY COMPLEXES: SELECTION OF THERMODYNAMIC PROPERTIES AND APPLICATION TO THE MODELLING OF A COLUMN EXPERIMENT
}

\author{
$\underline{\text { P. Blanc }}^{*}$, A. Burnol, N. Marty, J. Hellal, V. Guérin, V. Laperche
}

BRGM, 3 Avenue Claude Guillemin, 45060 Orléans Cedex 2, France

* Corresponding author: p.blanc@brgm.fr

\begin{abstract}
Complexation with methyl groups produces the most toxic form of mercury, especially because of its capacity to bioconcentrate in living tissues. Understanding and integrating methylation and demethylation processes is of the utmost interest in providing geochemical models relevant for environmental assessment. In a first step, we investigated methylation at equilibrium, by selecting the thermodynamic properties of different complexes that form in the chemical system $\mathrm{Hg}-\mathrm{SO}_{3}-\mathrm{S}-\mathrm{Cl}-\mathrm{C}-\mathrm{H}_{2} \mathrm{O}$. The selection included temperature dependencies of the equilibrium constants when available. We also considered adsorption and desorption reactions of both methylated and non-methylated mercury onto mineral surfaces. Then we assessed the kinetics of methylation by comparing a dedicated column experiment with the results of a geochemical model, including testing different methylation and demethylation kinetic rate laws. The column system was a simple medium: silicic sand and iron hydroxides spiked with a mercury nitrate solution. The modelling of methylmercury production with two different rate laws from the literature is bracketing the experimental results. Dissolved mercury, iron and sulfate concentrations were also correctly reproduced. The internal evolution of the column was also correctly modeled, including the precipitation of mackinawite (FeS) and the evolution of dissolved iron. The results validate the conceptual model and underline the capacity of geochemical models to reproduce some processes driven by bacterial activity.
\end{abstract}

Keywords: Methylmercury, reactive transport, percolation, sulfate reduction 


\section{Introduction}

Mercury $(\mathrm{Hg})$ is among the most toxic elements, and has many natural sources. Human activity, especially mining and the burning of coal, has increased the mobilization of mercury into the environment. For about 200 years, anthropogenic emissions have been greater than natural emissions (UNEP, 2013). Mercury occurs in various chemical forms. Most atmospheric $\mathrm{Hg}$ is gaseous elemental mercury $\left(\mathrm{Hg}^{0}\right)$. In surface water and soils it occurs as elemental mercury (droplets of liquid mercury) and as $\mathrm{Hg}(\mathrm{II})$ complexes (Kim et al., 2003). $\mathrm{Hg}$-containing minerals, such as cinnabar and metacinnabar (two polymorphs of $\mathrm{HgS}$ ) and montroydite $(\mathrm{HgO})$, can control its solubility (Kim et al., 2003). Much human exposure to mercury is through the consumption of fish and other marine foods, since mercury is mainly introduced into the food chain as methylmercury (MeHg). In soils, the presence of $\mathrm{MeHg}$ results from a balance between different competing processes (Skyllberg, 2012): methylation and demethylation (Cossa et al., 2014) reactions, formation of aqueous complexes and gaseous species and adsorption/desorption reactions onto inorganic and organic substrates. The balance between those different mechanisms determines bioaccumulation and $\mathrm{MeHg}$ transportation.

Researchers have begun to use geochemical modelling to assess the fate of mercury in the environment. Bessinger et al. (2012) have proposed a comprehensive model to reproduce mercury and arsenic speciation in sediment caps and how it changes over time, including MeHg. Leterme et al. (2014) also developed geochemical modelling of a conceptual soil, to assess the relative proportion of mercury release in the atmosphere or transported through the soil column or trapped, either onto mineral surfaces or as minerals precipitated along the profile.

71 Leterme et al. (2014) explained that in spite of being an important tool, geochemical modelling suffers from the lack of well characterized sites. Actually, the counterpart of being 
able to reproduce detailed reactive mechanisms is that those models may require an 6 9 8 9 important input dataset, including site-specific parameters. Even if determined, the values may suffer from variability and heterogeneities. As an alternative, we propose building a model to reproduce the results of a less complex column experiment. The model itself would include all the complexity governing $\mathrm{MeHg}$ fate, including methylation/demethylation reactions, the formation of aqueous complexes and gaseous species and surface complexation reactions. Johannesson and Neumann (2013) conducted a comprehensive set of measurements in groundwater along a $13 \mathrm{~km}$ flowpath located within a confined aquifer in southeastern Texas, USA. Their biogeochemical model was able to highlight the main mechanisms (mineral dissolution and sorption onto oxide surfaces) responsible for the speciation of total $\mathrm{Hg}$.

The aim of this study is to test geochemical modelling in a more controlled context like the column experiment performed by Hellal et al. (2015). The geochemical calculations on $\mathrm{Hg}$ fate can then be somehow constrained or compared with respect to those experimental results. In addition, taking advantage of the analyses performed by Hellal et al. (2015), the calculations are especially focused on methylmercury fate (methylation/demethylation and transportation), allowing testing of the methylation/demethylation rates available to date in the literature. Before comparing the calculations with the experimental results, we include a critical selection for MeHg complexes, consistent with the database built up by Leterme et al. (2014) for Hg-bearing species. The selection extended to surface complexation reactions and methylation/demethylation rates, following the review and case study proposed by Bessinger et al. (2012) and Cossa et al. (2014). 


\section{Selection of thermodynamic properties for methylmercury aqueous complexes}

104 Methylmercury is a strongly toxic complex that accumulates in the muscles and various living tissues of living organisms. After Thomassin and Touze (2003), the methylation of mercury is

106 favored in anoxic environments by the presence of sulfate-reducing bacteria and of sulfur.

107 Generally speaking, the methylation reaction proceeds this way:

108

$$
\begin{array}{cc}
\mathrm{Hg}^{++}+\mathrm{CH}_{4, \text { aq }} \stackrel{\text { Bacteria }}{\longrightarrow} \mathrm{CH}_{3} \mathrm{Hg}^{+}+\mathrm{H}^{+} & \text {Mono-MethylMercury (MMHg) } \\
\mathrm{CH}_{3} \mathrm{Hg}^{+}+\mathrm{CH}_{4, \mathrm{aq}} \stackrel{\text { Bacteria }}{\longrightarrow}\left(\mathrm{CH}_{3}\right)_{2} \mathrm{Hg}+\mathrm{H}^{+} & \text {Di-MethylMercury (DMHg) }
\end{array}
$$

111 Dimethyl products are found as both aqueous complexes (in basic solutions) and in gaseous

112 form. Methylation of mercury is reversible. We selected MeHg species using thermodynamic

113 data processed according to guidelines describes by Blanc et al. (2012) and consistent with

114 the previous selection by Leterme et al. (2014). The thermodynamic parameters associated 115 with complexation reactions have been collected and discussed from Erni (1977), Alderighi et 116 al. (2003), Loux (2007) and Skyllberg (2012), for various chemical systems, at $25^{\circ} \mathrm{C}$. Loux 117 (2007) are especially important, resulting from an extrapolation to infinite dilution of large 118 experiment datasets. Alderighi et al. (2003) have measured, by calorimetry, the heat 119 exchanged during various complexation reactions involving methylmercury. From these 120 measurements, we were able to calculate the entropy of complexes, which are reported in 121 Table 1. Actually, they provided $\Delta \mathrm{S}_{\mathrm{r}}$ for reactions involving $\mathrm{CH}_{3} \mathrm{Hg}^{+}$as primary specie. In 122 order to use these measurements, we have considered the reaction:

124 It was converted into an isocoulombic equilibrium using $\mathrm{Ca}++$ and $\mathrm{Ca}(\mathrm{OH})+$ species: 
126 The third law entropy was calculated considering the one term approximation method from

127 Gu et al. (1994) and entropies from the Thermoddem database (Blanc et al., 2012). The

128 result allows obtaining the third law entropies from Alderighi et al. (2003) measurements. The

129 whole results are reported in Table 1 . In addition to the aqueous complexes we have

130 included a gas phase, $\mathrm{Hg}\left(\mathrm{CH}_{3}\right)_{2, g}$ which represents an extreme stage of the methylation

131 process (Thomassin and Touze, 2003).

132

133

134

135

136

Table 1 - Selection for thermodynamic properties of MeHg-bearing species

\begin{tabular}{|c|c|c|c|c|}
\hline Specie & Equilibrium & $\begin{array}{c}\log _{10} K \\
(298.15 \mathrm{~K})\end{array}$ & $\begin{array}{c}\mathbf{S}^{\circ} \\
(\mathrm{J} / \mathrm{mol} . \mathrm{K})\end{array}$ & References \\
\hline $\mathrm{CH}_{3}^{-}$ & $\mathrm{CH}_{4, \mathrm{aq}}=\mathrm{CH}_{3^{-}}+\mathrm{H}^{+}$ & -46.00 & & $(1)$ \\
\hline $\mathrm{CH}_{3} \mathrm{Hg}^{+}$ & $\mathrm{CH}_{4, \mathrm{aq}}+\mathrm{Hg}^{++}=\mathrm{CH}_{3} \mathrm{Hg}^{+}+\mathrm{H}^{+}$ & 3.00 & 65.91 & (1), this work \\
\hline $\mathrm{CH}_{3} \mathrm{HgCl}$ & $\mathrm{CH}_{3} \mathrm{Hg}^{+}+\mathrm{Cl}^{-}=\mathrm{CH}_{3} \mathrm{HgCl}$ & 5.45 & 142.91 & (2), (3) \\
\hline $\mathrm{CH}_{3} \mathrm{HgOH}$ & $\mathrm{CH}_{3} \mathrm{Hg}^{+}+\mathrm{H}_{2} \mathrm{O}=\mathrm{CH}_{3} \mathrm{HgOH}+\mathrm{H}^{+}$ & -4.53 & 110.71 & (2), (3) \\
\hline $\mathrm{CH}_{3} \mathrm{HgS}^{-}$ & $\mathrm{CH}_{3} \mathrm{Hg}^{+}+\mathrm{HS}^{-}=\mathrm{CH}_{3} \mathrm{HgS}^{-}+\mathrm{H}^{+}$ & 4.00 & & $(2)$ \\
\hline $\mathrm{CH}_{3} \mathrm{HgSH}$ & $\mathrm{CH}_{3} \mathrm{Hg}^{+}+\mathrm{HS}^{-}=\mathrm{CH}_{3} \mathrm{HgSH}$ & 14.50 & & $(2)$ \\
\hline$\left(\mathrm{CH}_{3}\right)_{2} \mathrm{Hg}$ & $2 \mathrm{CH}_{3} \mathrm{Hg}^{+}=\left(\mathrm{CH}_{3}\right)_{2} \mathrm{Hg}+\mathrm{Hg}^{++}$ & 13.00 & & $(1)$ \\
\hline $\mathrm{CH}_{3} \mathrm{HgCO}_{3}^{-}$ & $\mathrm{CH}_{3} \mathrm{Hg}^{+}+\mathrm{HCO}_{3}^{-}=\mathrm{CH}_{3} \mathrm{HgCO}_{3}^{-}+\mathrm{H}^{+}$ & -4.23 & & (2) \\
\hline $\mathrm{CH}_{3} \mathrm{HgHCO}_{3}$ & $\mathrm{CH}_{3} \mathrm{Hg}^{+}+\mathrm{HCO}_{3}^{-}=\mathrm{CH}_{3} \mathrm{HgHCO}_{3}$ & 2.60 & & (2) \\
\hline $\mathrm{CH}_{3} \mathrm{HgSO}_{4}^{-}$ & $\mathrm{CH}_{3} \mathrm{Hg}^{+}+\mathrm{SO}_{4^{--}}=\mathrm{CH}_{3} \mathrm{HgSO}_{4}^{-}$ & 2.64 & & (2) \\
\hline$\left(\mathrm{CH}_{3} \mathrm{Hg}\right)_{2} \mathrm{OH}^{+}$ & $2 \mathrm{CH}_{3} \mathrm{Hg}^{+}+\mathrm{H}_{2} \mathrm{O}=\left(\mathrm{CH}_{3} \mathrm{Hg}\right)_{2} \mathrm{OH}^{+}+\mathrm{H}^{+}$ & -2.15 & 167.62 & (2), (3) \\
\hline$\left(\mathrm{CH}_{3} \mathrm{Hg}\right)_{2} \mathrm{~S}^{\mathrm{a}}$ & $\mathrm{CH}_{3} \mathrm{Hg}^{+}+\mathrm{CH}_{3} \mathrm{HgS}^{-}=\left(\mathrm{CH}_{3} \mathrm{Hg}\right)_{2} \mathrm{~S}$ & 20.32 & & $(2)$ \\
\hline $\mathrm{Hg}\left(\mathrm{CH}_{3}\right)_{2, \mathrm{~g}}$ & $\mathrm{Hg}^{++}+2 \mathrm{CH}_{4, \mathrm{aq}}=\mathrm{Hg}\left(\mathrm{CH}_{3}\right)_{2, \mathrm{~g}}+2 \mathrm{H}^{+}$ & 8.82 & 306.00 & $(4)$ \\
\hline
\end{tabular}

(1) Erni (1977); (2) Loux (2007); (3) recalculated using reaction entropy from Alderighi et al. (2003); (4) Wagman et al. (1982)

a. Not selected (see text)

For the selection, we followed the approach promoted by Stumm and Morgan (1996) where the methyl group is represented by the $\mathrm{CH}_{3}{ }^{-}$anion. This formally identifies the methylated complexes and easily separates the inorganic and organic chemical system when required.

The selection was integrated in the Thermoddem database (Blanc et al., 2012) in order to 
147 use it with geochemical codes GWB (Bethke, 2004) and PhreeqC (Parkhurst and Appelo, 148 1999).

150 A first test of the database consisted in calculating the production of methyl complexes which 151 would arise from the speciation model detailed in Table 1. After Leterme and Jacques 152 (2012), the amount of MeHg in waters in contact with soil systems is usually close to $2 \%$. A 153 speciation calculation is conducted, using PhreeqC-2 with the above database and 154 considering a solution with $[\mathrm{NaCl}]=$ with $10^{-3} \mathrm{M}$ and $[\mathrm{Hg}]=10^{-9} \mathrm{M}$. This amount was reached 155 applying two different corrections:

156 - by modifying reaction (2) equilibrium constant from $\log _{10} \mathrm{~K}=3$ to 2.5 when reactions from Table 1 a written with $\mathrm{CH}_{4, \text { aq }}$ as primary specie - or by modifying $\mathrm{CH}_{4, a q}=\mathrm{CH}_{3}{ }^{-}+\mathrm{H}^{+}$equilibrium constant from $\log _{10} \mathrm{~K}=-46$ to -52.5 when reactions from Table 1 a written with $\mathrm{CH}_{3}{ }^{-}$as primary specie.

Actually, we did not expect the relation between organic and inorganic carbon to be driven by thermodynamic equilibrium. The correction considered in the first test is still of small extent, especially because the value originally given by Erni (1977) was calculated and not measured and the uncertainty can be larger in that case. In addition, the fact that the results obtained for MeHg speciation may depend on the way the database is written is to be underline. For the rest of the calculations, we no longer consider the equilibrium between organic and inorganic reduced carbon. However it is important to note that when the database uses $\mathrm{CH}_{4, \text { aq }}$ or $\mathrm{CH}_{3}{ }^{-}$complexes as primary specie for the methylation reactions, this allows considering also the methylation for other metals like $\mathrm{Sn}$ or $\mathrm{Pb}$ (Stumm and Morgan, 1996), jointly with $\mathrm{Hg}$ methylation. The database in Table 1 was also tested using activity diagrams of which examples are displayed in Figure 1 

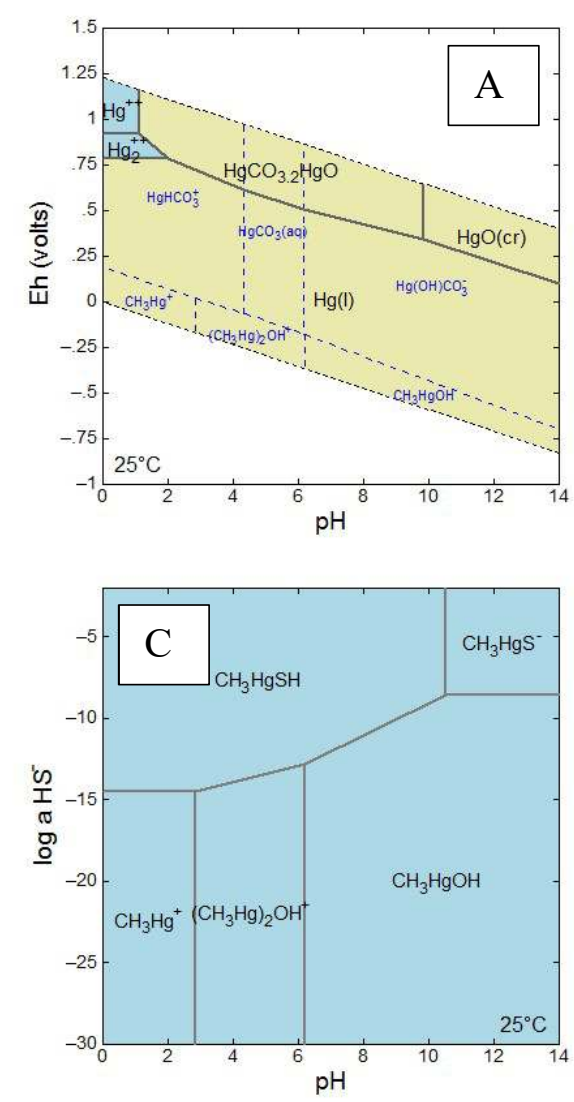

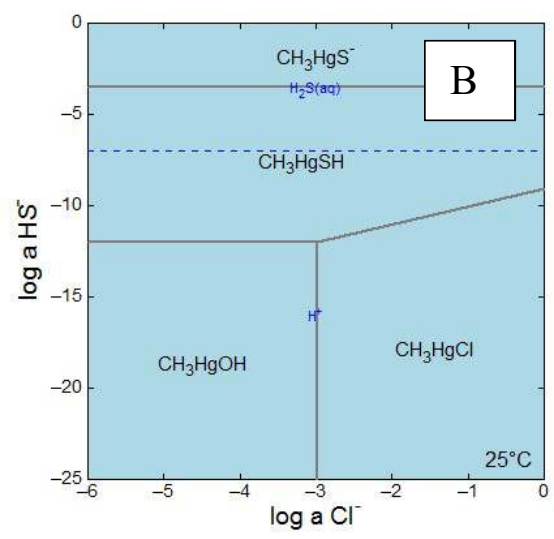

Figure 1 - Stability relation between $\mathrm{MeHg}$ aqueous complexes at $25^{\circ} \mathrm{C}$ : $\mathrm{A}$ - for the carbonate sub-system; $\mathrm{B}$ - depending on sulfide and chloride activity; $\mathrm{C}$ - depending on sulfide activity and $\mathrm{pH}$

In yellow: solid phase stability domains; in blue: aqueous complexes stability domains

The carbonate stability domains (Figure 1.A) are in agreement with Powell et al. (2005) calculations. As for methylmercury species, they are dominated by $\mathrm{CH}_{3} \mathrm{Hg}^{+},\left(\mathrm{CH}_{3} \mathrm{Hg}\right)_{2} \mathrm{OH}^{+}$ and $\mathrm{CH}_{3} \mathrm{HgOH}$ complexes and located in the reduced part of the predominance diagram. The equilibrium with dissolved carbonate species strongly reduces the methylmercury stability domain. Since most of the contaminated water contains $1 \%$ of total mercury as $\mathrm{MeHg}$, this would imply kinetic control of $\mathrm{MeHg}$ speciation. Figures 1.B and 1.C display a transition between sulfide and hydroxylated species for a total sulfide concentration close to $10^{-12}$ $\mathrm{mol} / \mathrm{L}$, whereas Boszke et al. (2002) proposed $10^{-11} \mathrm{~mol} / \mathrm{L}$. On the other hand the transition between chlorinated and hydroxylated methyl complexes occurs according to Boszke et al.'s calculation at $\mathrm{pH}=7$ (for a chloride concentration of about $10^{-3} \mathrm{~mol} / \mathrm{L}$ ). Previous results could only be obtained only by removing the $\left(\mathrm{CH}_{3} \mathrm{Hg}\right)_{2} \mathrm{~S}$ complex which displayed an exaggerated stability, covering most of the area in figures 1.B and 1.C. 


\section{Column experiment (Hellal et al., 2015)}

193 The database set up previously is now tested by modeling the MeHg rate obtained

194 experimentally by Hellal et al. (2015) in a companion. To our knowledge, such comparison is 195 rather unique for $\mathrm{Hg}$ methylation, up to now.

197 Only a brief description is given here and the reader referred to Hellal et al. (2015) for 198 additional details. The experiment design is reported in Figure 2. The lower half the column is

199 filled with sterile sand and the upper half with a sterile mixture of sand and iron oxides, 200 initially enriched with $\mathrm{Hg}(+2)$. The column is inoculated with a bacterial consortium and the 201 inflowing solution is supplemented with magnesium sulfate and sodium lactate to enhance 202 the growth and activity of sulfate-reducing bacteria (SRB). The water flow is ascendant. Five 203 septa set regularly along the columns enable water sampling from the different layers of the 204 column without perturbing water flow or in situ experimental conditions. After an abiotic 205 rinsing period, the system is inoculated with a bacterial consortium, and physical, chemical 206 and microbial parameters are monitored in time and space, up to 143 days. 


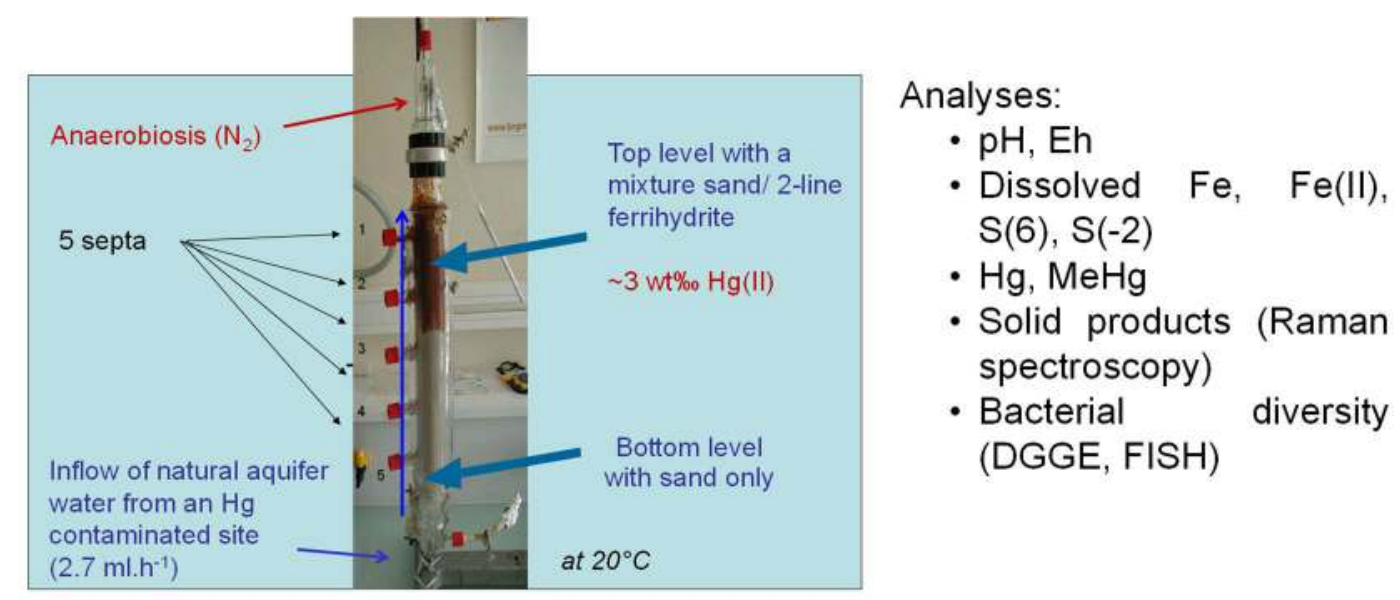

- Percolating water (mmol. $\left.\mathrm{L}^{-1}\right)$ : $\mathrm{pH} 7.22$, pe 2.28, [Ca] 1.41, [Cl] $0.42,[\mathrm{Na}] 0.30$, [S] 0.75, [Lactate] 0.01, [Fe] 1.80.10-7, [Hg] 1.6.10-9

- Solid matrix: $0-15 \mathrm{~cm}$ sand ; $15-30 \mathrm{~cm}$ sand + Ferrihydrite $2 \mathrm{~L}(5.7 \%)$

- Percolating water inoculated with SRB and FRB

- Percolating for 143 days

Figure 2 - Experimental design developed by Hellal et al. (2015)

\section{Model development}

A specific reactive transport model was developed to reproduce the experimental conditions.

Methylation is described in the model following a suite of chemical reactions described in

221 Figure 3, where $\mathrm{MeHg}$ formation arises from a rather complex process including different steps:

- a first step corresponds to the reduction of $\mathrm{Fe}(+3)$ from the dissolution of ferrihydrite. It is reproduced using the model developed by Poulton (2003)

- meanwhile, sulfate undergoes a reduction induced by the activity and growth of SRB bacteria. The reduction is modeled using a first order rate law which rate constant is extracted from Bharati and Kumar (2012) experiment (Table 2) 
- cobaltihexamine $\left(\mathrm{CoB}-\mathrm{CH}_{3}\right)$ complexes with mackinawite surfaces, the methyl group $\mathrm{CH}_{3}{ }^{-}$is released and combines in solution with dissolved mercury $\mathrm{Hg}^{++}$to form eventually the methylmercury complex $\mathrm{CH}_{3} \mathrm{Hg}^{+}$. Two rate laws were tested, a first order proposed by Bessinger et al. (2012) and a second law based on the work by Heyes et al. (2006) (Table 2) and which rate corresponds to a balance between both methylation and demethylation rates.

236 The possible formation of complexes at the ferrihydrite surface is implemented, using 237 capacity of ferrihydrite, using the Dzombak and Morel (1990) model and database. Numerical 238 modelling uses PhreeqC-2 code (Parkhurst and Appelo, 1999) and the Thermoddem database (Blanc et al., 2012). The conceptual model is based on 1D-cartesian geometry, as displayed in Figure 4. A tracer test has been successfully simulated to verify the

241 hydrodynamic set of parameters used.

\section{Reaction pathway tested}

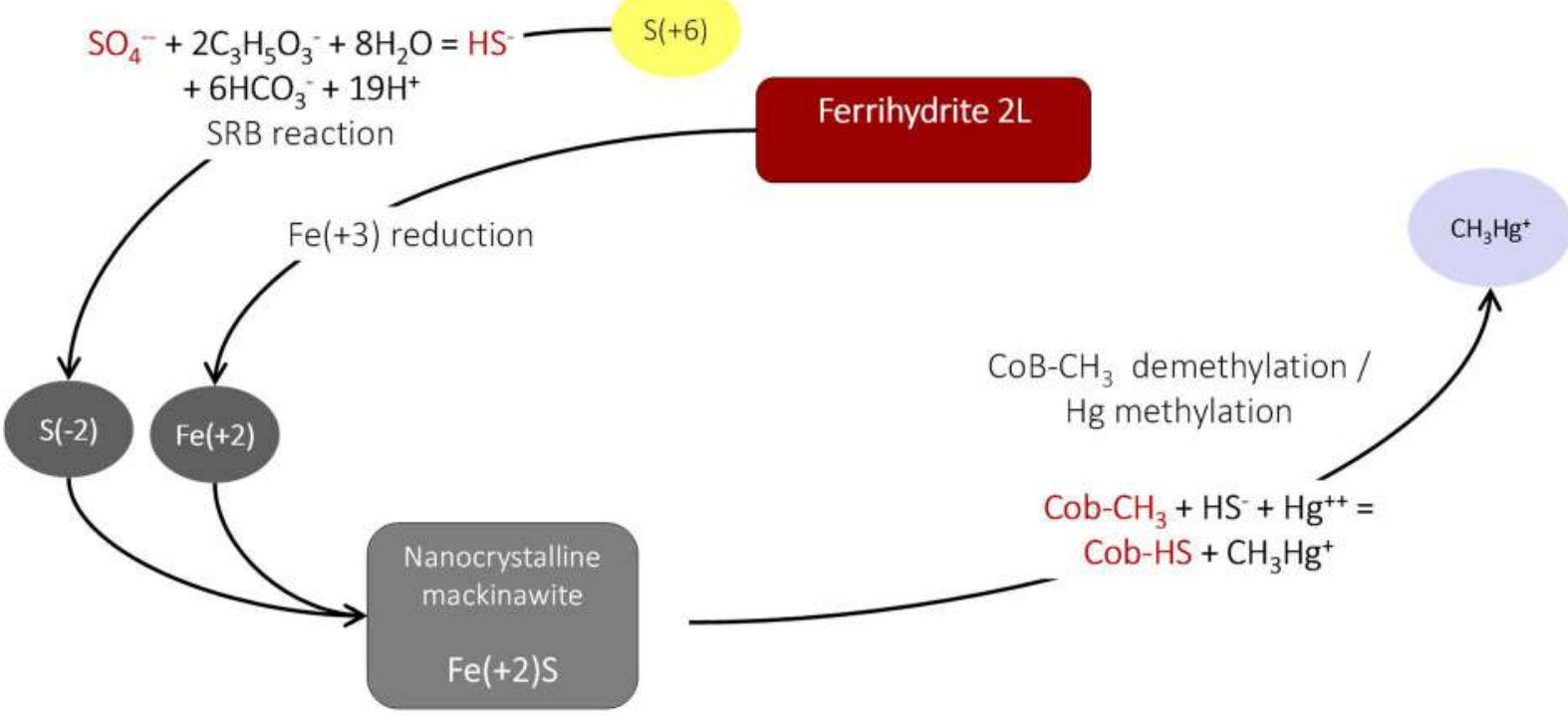




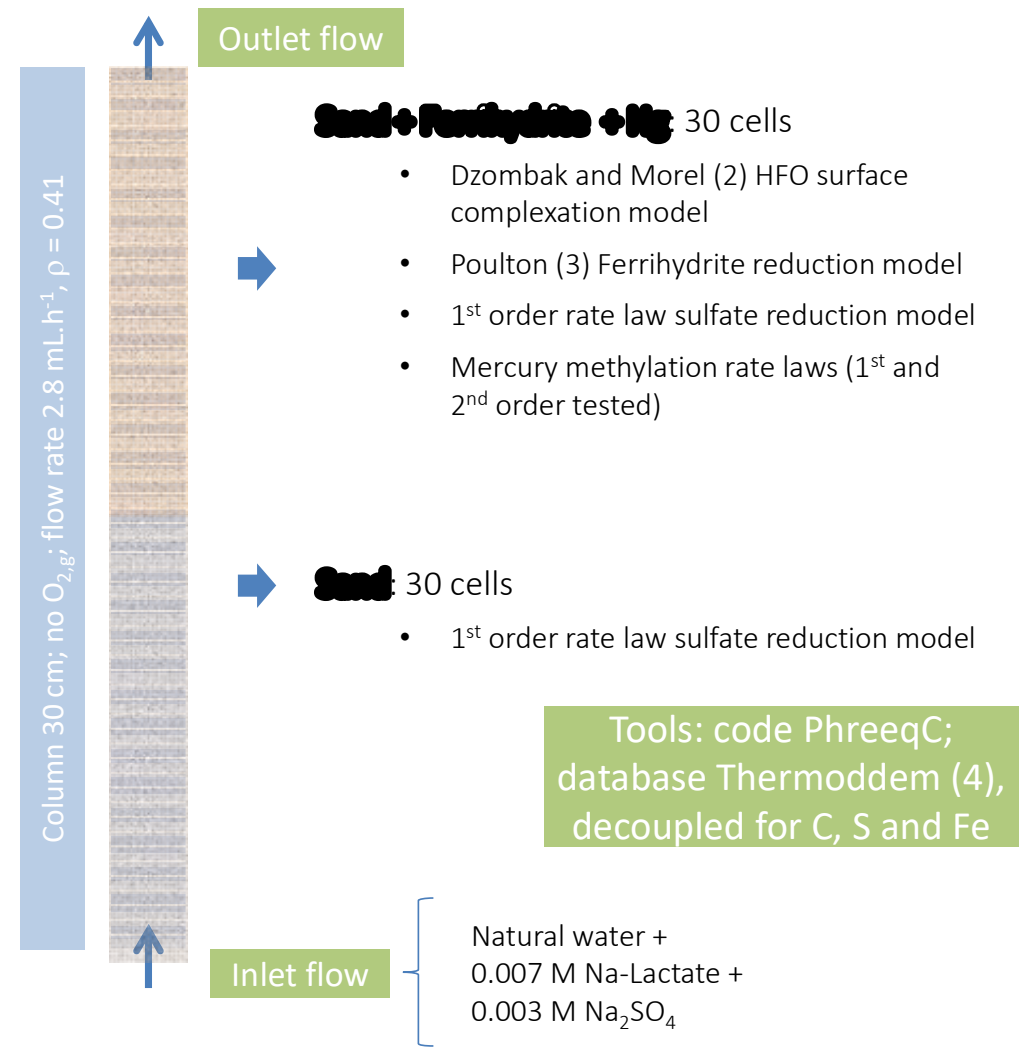

Figure 4-Conceptual model 
Table 2 - Main parameters for reactive transport modeling

\begin{tabular}{|c|c|c|c|}
\hline \multicolumn{4}{|c|}{ Chemical system } \\
\hline \multicolumn{4}{|l|}{ Minerals } \\
\hline Ferrihydrite & $\mathrm{Fe}(\mathrm{OH})_{3}+3 \mathrm{H}^{+}=\mathrm{Fe}^{+++}+3 \mathrm{H}_{2} \mathrm{O}$ & $\log _{10} \mathrm{~K}^{\circ}=3.40$ & Blanc et al. (2012) \\
\hline Mackinawite & $\mathrm{FeS}+\mathrm{H}^{+}=\mathrm{Fe}^{++}+\mathrm{HS}^{-}$ & $\log _{10} K^{\circ}=-3.54$ & Blanc et al. (2012) \\
\hline Schwertmannite & $\begin{array}{c}\mathrm{Fe}_{8} \mathrm{O}_{8}(\mathrm{OH})_{6} \mathrm{SO}_{4}: 8 \mathrm{H}_{2} \mathrm{O}+22 \mathrm{H}^{+}=8 \mathrm{Fe}^{+++}+\mathrm{SO}_{4}^{--}+ \\
22 \mathrm{H}_{2} \mathrm{O}\end{array}$ & $\log _{10} K^{\circ}=8.95$ & Blanc et al. (2012) \\
\hline Calcite & $\mathrm{CaCO}_{3}+\mathrm{H}^{+}=\mathrm{HCO}_{3}^{-}+\mathrm{Ca}^{++}$ & $\log _{10} K^{\circ}=1.85$ & Blanc et al. (2012) \\
\hline \multicolumn{4}{|c|}{ Aqueous species } \\
\hline $\begin{array}{l}\text { Thermoddem } \\
\text { database, } \\
\text { decoupled }\end{array}$ & $\begin{array}{c}\text { C decoupled into } \mathrm{C}(+4) \text { and } \mathrm{C}(-4) \\
\mathrm{S} \text { decoupled into } \mathrm{S}(+6) \text { and } \mathrm{S}(-2) \\
\text { Fe decoupled into } \mathrm{Fe}(+2) \text { and } \mathrm{Fe}(+3)\end{array}$ & $\begin{array}{l}\text { Percolating solution } \\
\text { given Figure } 2\end{array}$ & \\
\hline \multicolumn{4}{|c|}{ Surface complexation } \\
\hline $\begin{array}{l}\text { Ferrihydrite } \\
\text { surface }\end{array}$ & $\begin{array}{l}>\mathrm{Fe}^{\mathrm{s}} \mathrm{OH}+\mathrm{X}^{z}=>\mathrm{FeOX}^{(z-1)}+(z-1) \mathrm{H}^{+} \\
>\mathrm{Fe}^{\mathrm{w}} \mathrm{OH}+\mathrm{X}^{z}=>\mathrm{FeOX}^{(z-1)}+(z-1) \mathrm{H}^{+}\end{array}$ & $\begin{array}{c}\mathrm{X}^{\mathrm{z}}=\mathrm{Fe}^{++}, \mathrm{Hg}^{++}, \mathrm{Ca}^{++} \\
\mathrm{SO}_{4}^{--}, \mathrm{H}^{+}\end{array}$ & $\begin{array}{l}\text { Dzombak and Morel } \\
\qquad(1990)\end{array}$ \\
\hline $\begin{array}{l}\text { Mackinawite } \\
\text { surface }\end{array}$ & $>\mathrm{FeS}+\mathrm{CH}_{3} \mathrm{Hg}^{+}=>\mathrm{FeS}-\mathrm{CH}_{3} \mathrm{Hg}^{+}$ & $\log _{10} K^{\circ}=4.5$ & This study \\
\hline \multicolumn{4}{|c|}{ Kinetic transformations } \\
\hline Sulfate reduction & $\mathrm{SO}_{4}^{--}+2 \mathrm{C}_{3} \mathrm{H}_{5} \mathrm{O}_{3}^{-}+8 \mathrm{H}_{2} \mathrm{O}=\mathrm{HS}^{-}+6 \mathrm{HCO}_{3}^{-}+19 \mathrm{H}^{+}$ & $\mathrm{k}_{\mathrm{sr}}=610^{-7} \mathrm{~s}^{-1}$ & $\begin{array}{l}\text { Extracted from Bharati } \\
\text { and Kumar (2012) }\end{array}$ \\
\hline $\begin{array}{l}\text { MeHg formation } \\
\text { Fe reduction }\end{array}$ & $\begin{array}{l}\text { Model1: } \mathrm{k}_{1}\left(\mathrm{~s}^{-1}\right)=\left[\mathrm{Hg}(\mathrm{HS})_{2}\right] \cdot \mathrm{k}_{\mathrm{sr}} \cdot 4.210^{5} \\
\text { Model2: Cob-CH } \mathrm{CH}_{3}+\mathrm{HS}^{-}+\mathrm{Hg}^{++}=\mathrm{Cob}-\mathrm{HS}+\mathrm{CH}_{3} \mathrm{Hg}^{+} \\
\quad \mathrm{k}_{\mathrm{fe}}\left(\mathrm{s}^{-1}\right)=0.9210^{-6} \cdot[\text { Ferrihydrite }] \cdot[\mathrm{S}(-2)]^{0.5}\end{array}$ & $\mathrm{k}_{2}=1.310^{-7} \mathrm{~s}^{-1}$ & $\begin{array}{l}\text { Bessinger et al. (2012) } \\
\text { Heyes et al. (2006) } \\
\text { Poulton (2003) }\end{array}$ \\
\hline \multicolumn{4}{|c|}{ Physical parameters } \\
\hline $\begin{array}{l}\text { Porosity }=0.41 \\
\text { Inlet solution flow }\end{array}$ & Extracted from a preliminary tracing test & $\begin{array}{c}0.41 \\
2.8 \mathrm{~mL} / \mathrm{h}\end{array}$ & $\begin{array}{l}\text { This study } \\
\text { Hellal et al. (2015) }\end{array}$ \\
\hline
\end{tabular}




\section{Results and discussion}

286 The results were first verified at the column breakthrough point (Figure 5) and along the 287 column (Figure 6) for the longest reaction time (143 days). The reduction of sulfates was 288 correctly reproduced, globally. In that regard, Bharati and Kumar (2012) experiment was 289 selected because they were performing sulfate reduction by using lactate as substrate and 290 carbon source, as in our case. However, sulfate reduction appears somewhat 291 underestimated by the model, especially concerning sulfide production. The redox conditions 292 in the column (and departure to equilibrium conditions) could be questioned in that regard. 293 Dissolved $\mathrm{Fe}(+2)$ at the outlet was quite correctly predicted and calculations corresponding to 294 the concentrations measured in the different septa even matched the abrupt increase observed in the ferrihydrite-loaded part of the column. Such increase happens during a period when calcite precipitates. It also corresponds to the precipitation of Mackinawite, observed in the experiments by Hellal et al. (2015), using Raman spectroscopy. From the reaction displayed in Table 2, mackinawite precipitation happens to consumes protons which increases $\mathrm{pH}$ and can lead induce the precipitation of carbonates.

301 For dissolved mercury (Figure 5), the total concentrations were correctly predicted. Methylmercury concentrations analyzed were somewhat bracketed by the calculation 303 performed with the model proposed by Bessinger et al. (2012) and Heyes et al. (2006) 304 (Model 1 and Model 2 in Figure 5, and Table 2 respectively). The lowest concentrations 305 found using Heyes et al (2006) methylation rate law may possibly be explained because the 306 first order rate constant reported in Table 2 represent a balance between both methylation 307 and demethylation rates. Actually the global methylation budget usually arises from the competition between both mechanisms. 

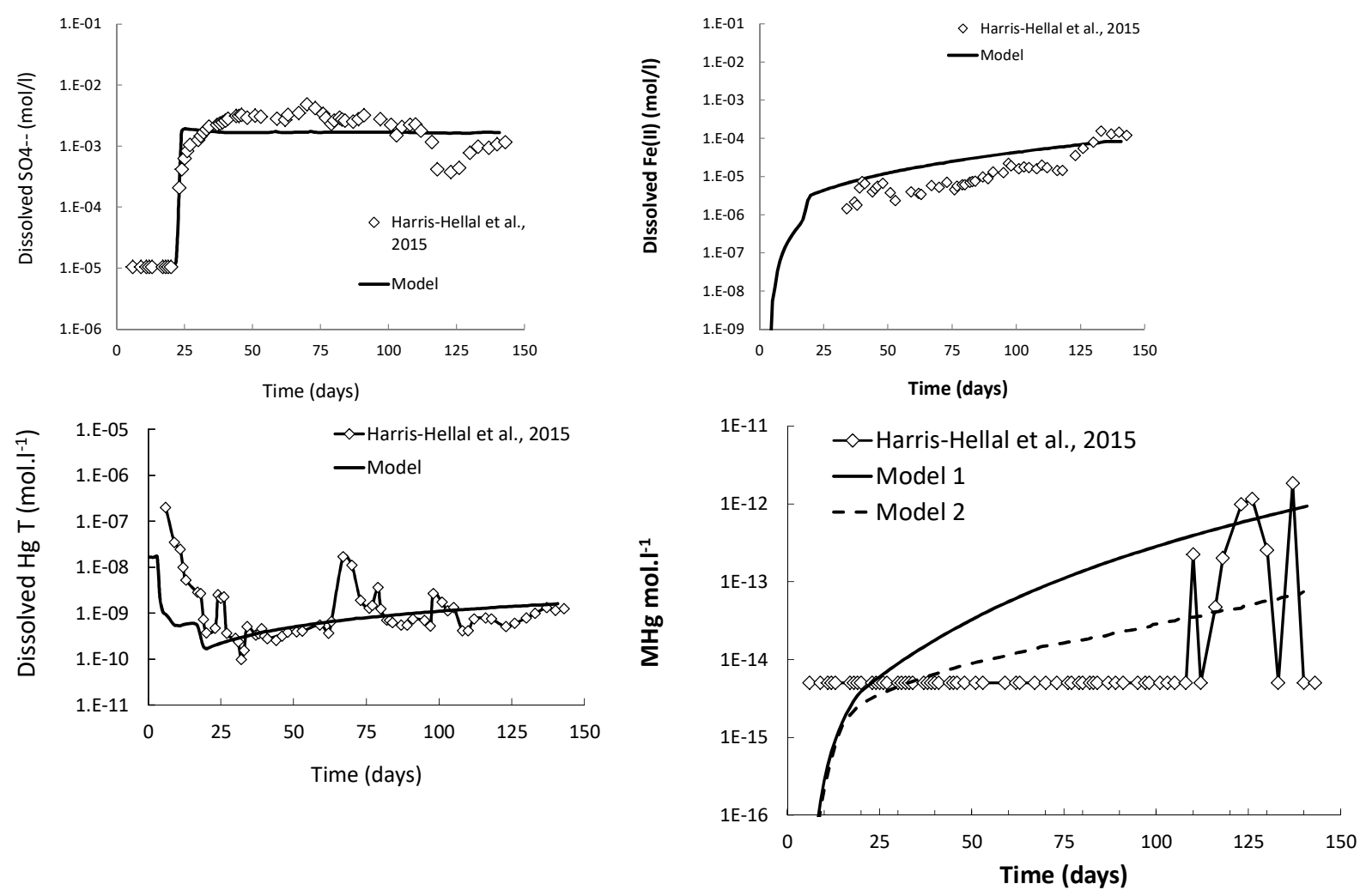

Figure 5 - Concentration in dissolved elements analysed at the outlet of the column
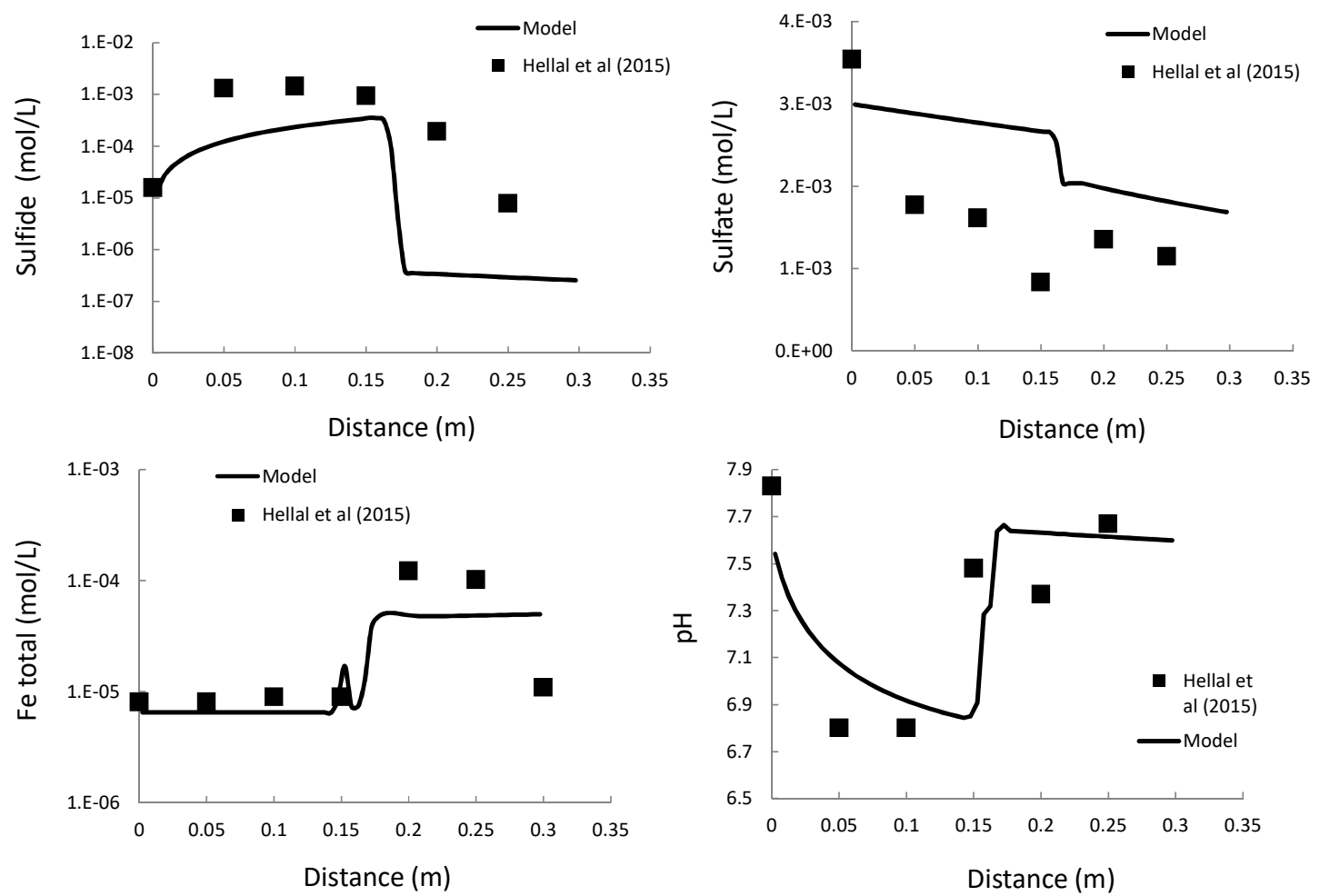

Figure 6 - Concentration in dissolved elements in the length of the column, after 143 days. 0 


\section{Conclusion}

323 The results obtained here are in line with previous works from Bessinger et al. (2012) and

324 Leterme et al. (2014). However, it displays a rare comparison between experiment and 325 reactive transport modelling results. It confirms the rate obtained by previous authors 326 concerning the mercury methylation process and it brings a confirmation to the reaction 327 pathways first proposed by Hellal et al. (2015) to explain their evolutions. The selection of 328 thermodynamic properties for MeHg complexes gave the opportunity to test different writing 329 for the $\mathrm{MeHg}$ database. The testing favored the discarding of the dimethyl complex $\left(\mathrm{CH}_{3}\right)_{2} \mathrm{Hg}$ 330 from the thermodynamic dataset. In addition, it enhances possible connections between 331 inorganic and organic dissolved carbon forms, from the point of view of methylation 332 processes. Such relations do probably not involve equilibrium reaction. There is a strong 333 need for additional experiment data to test such hypotheses, including measurements that 334 does not seems to be related, at first sight, like dissolved $\mathrm{CH}_{4}$ concentrations, for instance.

\section{ACKNOWLEDGEMENTS}

339 Financial support from the French Geological Survey (BRGM, Geomer Project) and from 340 the EU through the Snowman IMAHg project is gratefully acknowledged. The authors 341 would like to thank for BA Bessinger for his kind help. 


\section{References}

Alderighi L, Gans P, Midollini S, Vacca A. Co-ordination chemistry of the methylmercury(II) ion in aqueous solution: a thermodynamic investigation. Inorganica Chimica Acta

Bessinger BA, Vlassopoulos D, Serrano S, O'Day PA. Reactive Transport Modeling of Subaqueous Sediment Caps and Implications for the Long-Term Fate of Arsenic, Mercury, and Methylmercury. Aquatic Geochemistry 2012; 18: 297-326.

Bethke C. GWB Reference Manual: RockWare Incorporated, 2004.

Bharati B, Kumar GP. A study on efficiency of five different carbon sources on sulfate reduction. Journal of Environmental Research And Development Vol 2012; 7.

Blanc $\mathrm{P}$, Lassin A, Piantone $\mathrm{P}$, Azaroual $\mathrm{M}$, Jacquemet N, Fabbri A, et al. Thermoddem: A geochemical database focused on low temperature water/rock interactions and waste materials. Applied Geochemistry 2012; 27: 2107-2116.

Boszke L, Glosinska G, Siepak J. Some aspects of speciation of mercury in water environment. Polish Journal of Environmental Studies 2002; 11: 285-298.

Cossa D, Garnier C, Buscail R, Elbaz-Poulichet F, Mikac N, Patel-Sorrentino N, et al. A Michaelis-Menten type equation for describing methylmercury dependence on inorganic mercury in aquatic sediments. Biogeochemistry 2014; 119: 35-43.

Dzombak DA, Morel FM. Surface complexation modeling: hydrous ferric oxide: John Wiley \&

Erni Sons, 1990.

Gu Y, Gammons $\mathrm{CH}$, Bloom MS. A one-term extrapolation method for estimating equilibrium constants of aqueous reactions at elevated temperatures. Geochimica et Cosmochimica Acta 1994; 58: 3545-3560. 
374 Hellal J, Guédron S, Huguet L, Schäfer J, Laperche V, Joulian C, et al. Mercury mobilization and speciation linked to bacterial iron oxide and sulfate reduction: A column study to mimic reactive transfer in an anoxic aquifer. Journal of Contaminant Hydrology 2015; 180: 56-68.

Heyes A, Mason RP, Kim E-H, Sunderland E. Mercury methylation in estuaries: Insights from using measuring rates using stable mercury isotopes. Marine Chemistry 2006; 102 : 134-147.

Johannesson KH, Neumann K. Geochemical cycling of mercury in a deep, confined aquifer: Insights from biogeochemical reactive transport modeling. Geochimica et Cosmochimica Acta 2013; 106: 25-43.

Kim CS, Bloom NS, Rytuba JJ, Brown GE. Mercury Speciation by X-ray Absorption Fine Structure Spectroscopy and Sequential Chemical Extractions: A Comparison of Speciation Methods. Environmental Science \& Technology 2003; 37: 5102-5108.

Leterme $B$, Blanc $P$, Jacques $D$. A reactive transport model for mercury fate in soilapplication to different anthropogenic pollution sources. Environmental Science and Pollution Research International 2014.

Leterme B, Jacques D. Literature Review: Mercury fate and transport in Soil Systems. SCKCEN, Boeretang, 2012, pp. 21.

Loux NT. An assessment of thermodynamic reaction constants for simulating aqueous environmental monomethylmercury speciation. Chemical Speciation \& Bioavailability 2007; 19: 183-196.

Parkhurst DL, Appelo CaJ. User's guide to PHREEQC (Version 2) : a computer program for speciation, batch-reaction, one-dimensional transport, and inverse geochemical calculations. United States Geological Survey, 1999.

Poulton SW. Sulfide oxidation and iron dissolution kinetics during the reaction of dissolved sulfide with ferrihydrite. Chemical Geology 2003; 202: 79-94.

Powell KJ, Brown PL, Byrne RH, Gajda T, Hefter G, Sjöberg S, et al. Chemical speciation of environmentally significant heavy metals with inorganic ligands. Part 1: The $\mathrm{Hg} 2+-$ 

Cl-, OH-, CO32-, SO42-, and PO43- aqueous systems (IUPAC Technical Report). Pure and Applied Chemistry 2005; 77: 739-800.

404 Skyllberg U. Chemical Speciation of Mercury in Soil and Sediment. Environmental Chemistry and Toxicology of Mercury. John Wiley \& Sons, Inc., 2012, pp. 219-258.

406 Stumm W, Morgan JJ. Aquatic chemistry: chemical equilibria and rates in natural waters: Wiley, 1996.

408 Thomassin JF, Touze S. Le mercure et ses composés. Comportement dans les sols, les eaux et les boues de sédiments. Rapport final. , Orleans, 2003, pp. 119.

410 UNEP. Global Mercury Assessment 2013: Sources, Emissions, Releases and Environmental Transport, 2013, pp. 44.

412 Wagman DD, Evans WH, Parker VB, Schumm RH, Halow I, Balley SM, et al. NBS Tables of 413 Chemical Thermodynamic Properties: Selected Values for Inorganic and C1 and C2 414 Organic Substances in SI Units. Journal of Physical and Chemical Reference Data 415 1982; 11: 1-392.

416 